\title{
MORAL FETISHISM AND A THIRD DESIRE FOR WHAT'S RIGHT
}

\author{
Nathan Robert Howard
}

P

HILOSOPHERS who agree that the morally best kind of motivation requires a desire for what's right nevertheless disagree about how to understand that requirement. ${ }^{1}$ This disagreement originates in an ambiguity in the phrase "a desire for what's right," leading philosophers to defend different readings of the requirement. This debate seems to presuppose that the phrase has only two readings. However, outside of this debate, it is widely recognized that scope-ambiguous phrases like "a desire for what's right" have three distinct readings. The debate has wholly ignored the third reading. This paper describes it and argues that it claims some of the appealing features of the other two readings.

\section{IDENTIFYING THE THIRD READING}

In the context of the debate about whether moral judgments intrinsically motivate, Michael Smith reminds us that two very different kinds of desires can be described as desires to do what's right. ${ }^{2}$ The ambiguity in this description is a general feature of expressions that combine quantifiers, including, following Hintikka, attitude verbs like "desire," and phrasal complements. For example, "Jules wants to eat a Big Kahuna burger" is true of two distinct scenarios. In the first, Jules sees a specific burger and comes to want it, unaware that the burger is

1 Because the question of which motives are morally good is ancient, I focus on the discussion succeeding and informed by Smith, The Moral Problem. Earlier discussions from Copp ("Moral Obligation and Moral Motivation"), Lillehammer ("Smith on Moral Fetishism"), and Dreier ("Dispositions and Fetishes") focus on this question as it relates to moral judgment externalism. More recent discussions focusing on the nature of good moral motivation itself include Olson, "Are Desires De Dicto Fetishistic?”; Carbonnell, "De Dicto Desires and Morality as Fetish"; Sliwa, "Moral Worth and Moral Knowledge"; Aboodi, "One Thought Too Few"; and Isserow, "Moral Worth and Doing the Right Thing by Accident" and "Moral Worth."

2 Smith, The Moral Problem. 
a Big Kahuna burger. This scenario corresponds to the expression's de re reading. On the second, Jules has heard of Big Kahuna burgers and thinks of or cognizes the burgers he wants as Big Kahuna burgers. This scenario corresponds to the expression's de dicto reading.

The phrase "a desire to do what's right" also has de re and de dicto readings. The former implies a desire to do a particular action, which happens to be right. The latter implies a desire to do what the agent takes to be right, as such. Correspondingly, philosophers who agree that morally good motives require a desire to do what's right can still disagree about whether that claim is to be understood de dicto or de re. However, arguments in this debate often seem to presuppose that "a desire to do what's right" has only these two readings. This presupposition is false.

As Janet Fodor first showed, expressions like "Jules wants to eat a Big Kahuna burger" have a third reading, which she calls the nonspecific reading, contrasting this with the "specific de re" and "nonspecific de dicto" readings characterized above. ${ }^{3}$ The more familiar specific de re reading requires that Jules wants a specific burger. The de dicto reading requires that Jules cognizes his desired burgers as Big Kahuna burgers. However, "Jules wants to eat a Big Kahuna burger" can be true on the third reading even if neither of these conditions is met. For example, suppose that to be a Big Kahuna burger is to be a burger garnished with a pineapple slice and yellow hibiscus sauce-the pineapple slice and hibiscus sauce are essential to and sufficient for being a Big Kahuna burger. ${ }^{4}$ Jules tries a Big Kahuna burger for the first time, falling for its unique taste. If Jules craves any burger with pineapple and hibiscus, and, necessarily, only Big Kahuna burgers combine those ingredients, then we can accurately report Jules's craving with "Jules wants to eat a Big Kahuna burger." But suppose that Jules does not want a particular burger nor do his desires deploy the concept Big Kahuna burger- that is, Jules does not cognize his desired burgers as Big Kahuna burgers. So the report is not true on either its specific de re or de dicto reading. But it is true on its nonspecific reading for Jules has a de re desire for a particular kind of burger, of which only certain burgers are members. ${ }^{5}$

3 Fodor, The Linguistic Description of Opaque Contexts. For further discussion of the nonspecific reading, see Bäeurle, "Pragmatisch-semantisch Aspekte der NP-Interpretation"; Von Fintel and Heim, "Beyond De Re/De Dicto"; Égré, "Hyperintensionality and De Re Beliefs"; and Keshet and Schwartz, "De Re/ De Dicto."

4 In this sense, "Big Kahuna burger" operates more like "shepherd's pie," denoting the result of a particular combination of ingredients, than it does "Brand $X$ burger," a burger by Brand $X$.

5 Although there is widespread consensus about how to represent nonspecific de dicto and specific de re readings, representing the nonspecific reading is more controversial. Von Fintel and Heim offer the following logical form as the "standard" intentional approach to representing the reading's logical form: 
Since "Jules wants to eat a Big Kahuna burger" and "Jules desires to do what's right" share the relevant scopal features, the latter also allows a nonspecific reading. ${ }^{6}$ The former is true on this reading when Jules wants a particular kind of burger but he does not want a particular burger and he does not desire that kind of burger under the description "Big Kahuna burger." Likewise, the latter is true on this reading when Jules desires to perform a particular kind of act but he does not want to perform any act in particular and he does not cognize the kind of act that he wants to perform as the morally right kind.

For example, suppose (strictly for the purposes of illustration) that act utilitarianism is true so that an act is morally right just when and because it maximizes the balance of pleasure over pain. Imagine that Jules performs a pleasure-maximizing act and is overcome with a warm tingle. Because of the tingle, Jules wants to do more acts of that pleasure-maximizing kind, which happen to be all and only the morally right acts. "Jules desires to do what's right" is true on its nonspecific reading in this situation. Jules desires to perform a particular kind of action-the morally right kind-even though he does not desire it under that description. ${ }^{7}$

As a result, there is cause to recognize a third position in the debate about which desires underlie morally good motivation: morally good motivation might require a nonspecific desire to do what's right. This unacknowledged position is significant for two reasons. First, as I have already suggested, debate

$\operatorname{Jules~wants}_{w}\left[\lambda w^{\prime}\left[\right.\right.$ a Big-Kahuna-burger $\left.{ }_{w}\right] \lambda x\left[\right.$ PRo to eat $\left.\left._{w^{\prime}} x\right]\right]$

The formalization expresses, roughly, that in all of the worlds where Jules gets what he wants, he eats any burger that is actually a Big Kahuna burger.

6 That the latter sentence involves an embedded wh question clouds the scopal similarities of the two sentences somewhat. However, Groenendijk and Stokhof ("Semantic Analysis of 'Wh' Complements" and Studies in the Semantics of Questions and the Pragmatics of Answers) demonstrate that interrogative phrases like "what's right" produce scopal ambiguities when embedded in opaque contexts. In particular, "Jules desires to do what's right" has the same scopal ambiguities as "Jules desires to do an act that is right." Using von Fintel and Heim's "standard" approach, we can represent the latter claim's logical form as:

$\operatorname{Jules~wants}_{w}\left[\lambda w^{\prime}\left[\right.\right.$ a right-act $\left._{w}\right] \lambda x\left[\right.$ PRo to $\left.\left.\mathrm{do}_{w^{\prime}} x\right]\right]$

Roughly, when Jules satisfies the reading corresponding to this form, in all the worlds where he does what he desires, he does any act that is actually a morally right act. See also Sharvit ("Embedded Questions and 'De Dicto' Readings") for a particularly nuanced discussed of the scopal properties of embedded questions. For a related discussion concerning logic, see Woods, "Logical Indefinites."

7 Of course, utilitarianism is probably not the true moral theory. There is likely a plurality of potentially right-making features, which includes being pleasure maximizing along with being fair, being just, and being honest. Consequently, the motivational structure required to satisfy the nonspecific reading will also have to be pluralistic. I have assumed utilitarianism only for the purposes of exposition. 
about moral motivation often seems to presuppose that individuals can desire to do what's right in only two ways. Second, the third reading combines some of the most attractive features of the first two readings, providing an attractive new basis for theorizing. I will briefly explore these two features after articulating a controversial assumption on which I will rely throughout.

\section{NONSPECIFIC DESIRES AND OPAQUE CONTEXTS}

Attitude terms create so-called opaque linguistic environments where the substitution of intensionally equivalent terms fails to preserve truth. For example, "Clark Kent" and "Superman" are intensionally equivalent, denoting the same individual in all possibilities. ${ }^{8}$ However, Lois Lane might believe that Clark Kent wears glasses without believing that Superman wears glasses. Substituting "Clark Kent" with an intensionally equivalent term, like "Superman," under the scope of an attitude verb affects the sentence's truth conditions.

According to an orthodox explanation of this phenomenon, whether an attitude report is true depends on whether the sense of a given claim matches the sense in which the believer accepts it. The description or "sense" that Lois associates with the claim that Clark Kent wears glasses differs from the sense that she attaches to the claim that Superman wears glasses. ${ }^{9}$ That sense matches the sense expressed by "Clark Kent wears glasses" but not "Superman wears glasses" even though those claims are intensionally equivalent.

Like beliefs, desires are widely assumed to be propositional attitudes. Unsurprisingly then, desire ascriptions, like belief ascriptions, do not seem to support the inter-substitution of intensionally equivalent terms under the scope of "desire." Just as above, Lois may want to kiss Superman even if she does not want to kiss Clark Kent. That is because the sense in which she desires to kiss someone involves a description that she attaches to "Lois kisses Superman" but not to "Lois kisses Clark."

Rather, a desire attribution is true, I will assume, only if the agent desires the relevant object under the description associated with the attribution. On an appealingly simple (but optional) way of thinking about this phenomenon, desires must deploy the concepts expressed by a given description to desire an object under that description. ${ }^{10}$ On this approach, even if woodchucks are necessarily groundhogs, Lois can desire to adopt a woodchuck but not a groundhog (each de

8 I will assume that a single individual can belong to distinct worlds.

9 I am using "sense" broadly and loosely. I explicitly disavow Fregean commitments inessential to the account, whichever those are.

10 I am assuming this approach simply for concreteness. The account that I propose is consis- 
dicto) if her desires deploy the concept woodchuck but not groundhog. Likewise, even if utilitarianism is true and what's right is necessarily what's pleasure-maximizing, Jules can desire to do what's pleasure-maximizing but not what's right (each de dicto), if his desires deploy is pleasure-maximizing but not is right.

As a special case of this phenomenon, unless Jules desires what's right under the right description, he does not satisfy "Jules desires to do what's right," on its nonspecific reading. What is the right description? I will assume, controversially, that the description picks out the kind through the features distinctive of that kind. For example, a burger is a Big Kahuna burger in virtue of its pineapple slice and yellow hibiscus sauce. Consequently, this assumption implies that Jules satisfies "Jules wants a Big Kahuna burger," on its nonspecific reading, only if Jules desires any burger that is garnished by a pineapple slice and yellow hibiscus sauce. ${ }^{11}$ More generally, I will assume that an agent $A$ satisfies "wants what's $K$," on its nonspecific reading, only if (a) something belongs to $K$ in virtue of being $F$ and (b) $A$ wants anything that is $F$ in virtue of its being $F$, for a suitably restricted domain of Fs. In short, I am assuming that an agent nonspecifically desires a member of a kind when the features that explain why an object belongs to a kind match the features that explain why the agent desires the object.

This assumption implies that Jules nonspecifically desires to do what's right only if (a) an act is right in virtue of being $F$ and (b) Jules wants to do anything that is $F$, for a suitably restricted domain of Fs. It is widely assumed that something is right just when and because its right-making features outweigh its wrong-making features-just when its right-making features are sufficient. Consequently, only if Jules is attracted to the kind of actions whose right-making features are sufficient in virtue of their sufficiency does Jules satisfy "Jules desires to do what's right" on its nonspecific reading, according to the view that I am sketching.

These claims are plausible but highly controversial. They presuppose not only that attitude ascriptions are hyperintensional but also that nonspecific desire attributions are sensitive to the features in virtue of which an object belongs to the desired kind. A deeper examination of nonspecific desire attributions may very well cast doubt on these assumptions. Nevertheless, there is room for them at

tent with other accounts of what it takes to have an attitude under a description that does not rely on concepts.

This domain of burgers, over which "any burger" quantifies, is plausibly restricted: even though Jules wants a Big Kahuna burger, in the nonspecific sense, it goes without saying that he does not want a burger that has been dropped on the floor, even if it has a pineapple slice and yellow hibiscus sauce. The domain of burgers that Jules desires is restricted to those that have not been dropped on the floor. Consequently, "anything" in (b) quantifies over only a restricted set of Fs. For more, see Fara, "Specifying Desires"; Braun, "Desiring, Desires, and Desire Ascriptions"; and Philips-Brown and Grant, "Getting What You Want." 
this relatively early stage of inquiry: no sustained discussion of the hyperintensional features of nonspecific attitude ascriptions yet exists. As such, although my claims may be controversial, they are also uncontested. I will therefore assume them given the apparent need for at least a minimal theory of sense for a plausible theory of nonspecific desire attribution.

\section{APPLYING THE THIRD READING}

I have just offered a brief sketch of the truth conditions for attributions of nonspecific moral motivation. An agent $A$ satisfies "desires to do what's right" on the nonspecific reading, just when $A$ desires to do the morally right kind of action in virtue of the features that make those acts morally right. Note that desiring a kind of object in virtue of a certain feature shared by that kind does not require believing that the kind shares that feature. Jules can desire a Big Kahuna burger in virtue of its hibiscus sauce without believing anything about hibiscus sauce. Jules can just think, "Mmhmm! This is a tasty burger!" without reflecting on what makes the burger tasty. Rather, Jules satisfies the attitude ascription because what explains Jules's desire for the burger is the fact that it is topped with pineapple and hibiscus sauce. Likewise, I need not believe that an act is right in virtue of its right-making features being sufficient in order to satisfy "Nathan desires to do what's right" on the nonspecific reading. It suffices that my desire for that kind of act is explained by the fact that those acts possess features that make them right.

As we will now see, nonspecific moral motivation, so construed, offers an attractive middle ground between the two dominant positions in the debate over what constitutes good moral motivation. The first position holds that good moral motivation requires a noninstrumental desire for what's right de re. ${ }^{12}$ The second position holds that good moral motivation requires a noninstrumental desire for what's right de dicto. Each position has clear virtues: the first but not the second entails that good moral motivation requires doing what is in fact right. The second but not the first entails that good moral motivation requires acting out of respect for morality. The rest of the paper sketches a case for the claim that nonspecific moral motivation exemplifies each of these virtues without succumbing to their vices, which I will now discuss.

Smith rejects desiring to do what's right, de dicto, on the grounds that it inappropriately "fetishes" rightness itself, which risks alienating the agent from the

12 I am restricting my claims to noninstrumental motivation, desires that are not in the service of promoting further desires. De re or de dicto motivation that is strictly instrumental on nonmoral concerns is plainly not the morally best kind of motivation, so irrelevant for my purposes. 
features that make acts right, such as that they are just or fair. ${ }^{13}$ Smith supports this position by rehearsing a point from Bernard Williams. ${ }^{14}$ Williams describes a case from Fried where a husband can save either his wife or a stranger from drowning. Williams observes that, with sufficient philosophical ingenuity, we can wring the clearly correct implication that the husband may save the wife rather than the stranger from impartial moral theories like Kantian deontology or utilitarianism. These Kantian and utilitarian justifications, however, involve one thought too many. It should not matter to the husband that the stranger lost a fair lottery or that the husband's maxim of action can be universalized, argues Williams; it matters only that the husband's wife is drowning. On Smith's reading, bizarre moral deliberations like those apparently recommended by Kantianism and utilitarianism seem motivated by a de dicto desire for what's right. It would be inappropriate or fetishistic for the husband to have this desire because it seems to displace a desire for his wife's well-being. De dicto desires to do what's right are thus fetishistic because they supplant desires for what actually matters more generally, such as obligations to our loved ones, our promises, generalized benevolence, and so on.

This first criticism is complemented by a second. While it may seem bad to displace the husband's desire for his wife's well-being, that is genuinely worrying only if the husband's new desire is in some sense worse than the old one. Williams's case does not entail that a desire for rightness as such is bad; it merely suggests it. Smith regards its badness as common sense. I agree. However, we could reasonably ask for an argument for this claim.

Drawing on observations from Philip Stratton-Lake, Jonathan Dancy, and, ultimately, Philippa Foot concerning the "verdictive" nature of rightness, we might hold that goodness is a measure of value. ${ }^{15}$ Something is good when it is of sufficient value, just as something is tall when it is of sufficient height. But just as it is a mistake to think that tallness has a certain quantity of height rather than being a measure of a certain quantity of height, it is a mistake to think that goodness has a certain quantity of value rather than being a measure of a certain quantity of value. If goodness merely represents a degree of value but does not itself possess value (just as tallness does not have a height), and if it is not good to desire the valueless, then it is not good to desire goodness itself, apart from desiring good things. Similarly, moral rightness can be understood as simply a measure of support by moral reasons. Desiring the property of moral rightness

13 Smith, The Moral Problem.

14 Smith, The Moral Problem, 75; Williams, "Persons, Character, and Morality."

15 Stratton-Lake, Kant, Duty, and Moral Worth; Dancy, Ethics without Principles and "Should We Pass the Buck?" 
itself, as suggested by the de dicto reading, desires the measure and not what is measured, which is what genuinely deserves moral concern. This is why many philosophers find the de dicto account of moral motivation unappealing.

However, the competing de re account is not without its faults either. In particular, a de re desire for what's right does not suffice for the morally best kind of motivation. Plausibly, such motivation requires being motivated to perform a morally right action. Acting with a de re desire for what's right entails acting rightly. But it does not suffice for the morally best kind of motivation: "morally worthy" motivation. Famously, the shopkeeper in Kant's Groundwork wants to treat his customers honestly. ${ }^{16}$ Treating his customers honestly is the right thing to do. Consequently, the shopkeeper desires to do what's right, read de re. However, it turns out that this shopkeeper is indifferent to morality; he does not act out of respect for the moral law as such. Rather, he is completely selfish. Ordinarily, this selfishness would lead him to defraud his customers. However, the shopkeeper believes that his shop will succeed only if it has a reputation for honesty. Consequently, the shopkeeper's selfishness leads him to desire to do what's right, de re. But his motives are clearly morally deficient. As a result, de re moral motivation is insufficient for good moral motivation.

While some, most explicitly Markovits, defend the de re approach to moral motivation against challenging cases like Kant's shopkeeper through a match between the noninstrumental moral reasons for an action and the agent's noninstrumental motivating reasons for the action, others argue that de re moral motivation is incompatible with moral worth. ${ }^{17}$ According to Paulina Sliwa and likeminded philosophers such as Zoe Johnson King, de re motivation only ever produces accidentally right actions because the right-making features that sometimes underlie de re desires are defeasible. ${ }^{18}$ For example, just because an act is, for example, fair does not entail that it is right-the fair division of disputed land may have catastrophic effects that make the fair division wrong. As such, right-making features, as opposed to rightness itself, are only contingently right-making. Sliwa argues that de re motivation premised on right-making features therefore produces only contingently_indeed, argues Sliwa, only acciden-

Kant, Groundwork for the Metaphysics of Morals.

See Markovits, “Acting for the Right Reasons.” I think that challenges to Markovits's account flow from misunderstanding the ontology of reasons. I defend an analysis that closely resembles hers by rethinking the ontology of reasons in Howard, "The Goals of Moral Worth.” For a competing but similar approach, see Portmore, "Moral Worth and Our Ultimate Moral Concerns.” 
tally —right action. As such, de re motivation cannot be the morally best kind of motivation. ${ }^{19}$

To sum up, both (noninstrumental) de re and de dicto moral motivation have attractive features: the former entails that the performed act is right, the latter entails that the act is performed out of explicitly moral concern. However, each approach is flawed. The former allows for the accidental overlap of morally right action with nonmoral motivation, as in the case of Kant's shopkeeper. The latter risks alienating the agent from the features of right actions that merit nonderivative concern, such as fairness, justice, the promotion of equality, honesty, and the like.

As I will now argue, nonspecific moral motivation-at least the version that I have laid out above-appears to share these two strengths without the two weaknesses. Conclusively establishing that this is true requires more space than I have here. So I will make a provisional case for nonspecific moral motivation, which I hope will spur further interest from philosophers interested in virtue and moral motivation.

De re moral motivation is appealing partly because it entails that the performed action is morally right. Nonspecific moral motivation shares this virtue. Just as "Jules wants a Big Kahuna burger" is true on its nonspecific reading only if the burgers that Jules wants are in fact Big Kahuna burgers, "Jules wants to do what's right" is true on its nonspecific reading only if what Jules wants to do is in fact morally right. De dicto motivation does not have this implication. Agents with false beliefs about what's right desire to do what's right, de dicto, but their desires require them to break the moral law, not follow it.

In spite of this flaw, de dicto moral motivation is attractive because it entails a concern for morality. It involves moral concern because it deploys the concept morally right. Nonspecific moral motivation also seems to entail a concern for morality, although of a different sort. For example, Jules has a nonspecific desire for a Big Kahuna burger in virtue of desiring a particular kind of burger. His desire for the Big Kahuna kind of burger, rather than another kind of burger, is explained by the very features that make a burger a Big Kahuna burger-the pineapple slice and hibiscus sauce. Likewise, Jules has a nonspecific desire for what's right in virtue of desiring a particular kind of act without desiring that kind under the description morally right. His desire for the morally right kind of action, rather than any other kind of action, is explained by the strength of the features that make the act right, such as its fairness or honesty. Consequently, Jules desires what's right, on the nonspecific reading, only if he is concerned with 
the features that make acts right. So nonspecific moral motivation clearly entails a concern for morality.

It also appears that nonspecific moral motivation lacks the flaws associated with de re and de dicto motivation, respectively. As we saw with Kant's shopkeeper, de re motivation allows for only accidentally right action when doing what's morally right accidentally overlaps with what promotes the agent's nonmoral desires. Because nonspecific moral motivation, in contrast, implies that the agent desires a kind of action, it rules out many cases of accidental overlap. The shopkeeper desires to do what's right, de re, but he does not desire to do the right kind of action. So he lacks a nonspecific desire for what's right. To be clear, there is still room for some accidental overlap in cases of nonspecific moral motivation, as when an agent (nonspecifically) desires to do what's right in order to be praised. But it seems that we can rule out this kind of overlap by restricting our attention to noninstrumental, nonspecific moral motivation.

Finally, nonspecific moral motivation, unlike de dicto motivation, is not subject to the charge that it embodies a kind of moral fetishism that risks alienating an agent from the features of actions that make them right, which merit nonderivative concern. As we have seen, just as motivation by the features that make something a Big Kahuna burger is necessary for satisfying "Jules wants a Big Kahuna burger" on its nonspecific reading, motivation by the features that make actions morally right is necessary for satisfying "Jules wants to do what's right" on its nonspecific reading. Consequently, nonspecific moral motivation does not alienate agents from the features of actions that make them right. On the contrary, it implies motivation by them.

I fall short of full-throated endorsement of nonspecific moral motivation. The features that make nonspecific moral motivation attractive are at least partly grounded in contestable claims about hyperintensionality and how it constrains desire attributions. Nevertheless, nonspecific moral motivation clearly deserves attention from theorists working on questions of moral worth and moral fetishism, beyond discussion here. ${ }^{20}$

Texas A $\mathrm{M}$ University nrhoward@tamu.edu

This paper originated in a reading group with Caleb Perl and Jonathan "Disco" Wright on Von Fintel and Heim's Intensional Semantics during summer 2014 at the University of Southern California. Particular thanks to them for many happy memories. Thanks also to, in no particular order, Mark Schroeder, Steve Finlay, Ralph Wedgwood, Nate Charlow, Nicholas Laskowski, Renee Bolinger, Maegan Fairchild, Joe Horton, Alex Dietz, Kenneth Silver, Max Hayward, and Kenny Easwaran. 


\section{REFERENCES}

Aboodi, Ron. "One Thought Too Few: Where De Dicto Moral Motivation Is Necessary." Ethical Theory and Moral Practice 20, no. 2 (April 2017): 223-37. Bäuerle, Rainer. "Pragmatisch-semantisch Aspekte der NP-Interpretation." In Allgemeine Sprachwissenschaft, Sprachtypologie und Textlinguistik: Festschrift für Peter Hartmann, edited by Manfred Faust, Roland Harweg, Werner Wienold, and Götz Lehfeldt, 121-31. Tübingen, Germany: Gunter Narr, 1983.

Braun, David. "Desiring, Desires, and Desire Ascriptions." Philosophical Studies 172, no. 1 (January 2015): 141-62.

Carbonell, Vanessa. "De Dicto Desires and Morality as Fetish." Philosophical Studies 163, no. 2 (March 2013): 459-77.

Copp, David. "Moral Obligation and Moral Motivation." Canadian Journal of Philosophy Supplementary Volume 21 (1995): 187-219.

Dancy, Jonathan. Ethics without Principles. Oxford: Oxford University Press, 2000.

—_. "Should We Pass the Buck?" In Recent Work on Intrinsic Value, edited by Toni Rønnow-Rasmussen and Michael J. Zimmerman, 33-44. Dordrecht: Springer, 2005.

Dreier, James. "Dispositions and Fetishes: Externalist Models of Moral Motivation." Philosophy and Phenomenological Research 61, no. 3 (November 2000): $619-38$.

Égré, Paul. "Hyperintensionality and De Re Beliefs." In Epistemology, Context, and Formalism, edited by Franck Lihoreau and Manuel Rebuschi, 213-44. New York: Springer, 2014.

Fara, Delia Graff. "Specifying Desires.” Noûs 47, no. 2 (June 2013): 250-72.

Fodor, Janet Dean. The Linguistic Description of Opaque Contexts. 1979. Abingdon, UK: Routledge, 2014.

Groenendijk, Jeroen, and Martin Stokhof. "Semantic Analysis of 'Wh' Complements." Linguistics and Philosophy 5, no. 2 (1982): 175-233.

- Studies in the Semantics of Questions and the Pragmatics of Answers, $\mathrm{PhD}$ dissertation, University of Amsterdam, 1984.

Howard, Nathan Robert. "The Goals of Moral Worth." Oxford Studies in Metaethics, forthcoming.

. "One Desire Too Many." Philosophy and Phenomenological Research 102, no. 2. (2021): 302-317.

Isserow, Jessica. "Moral Worth and Doing the Right Thing by Accident." Australasian Journal of Philosophy 97, no. 2 (2019): 251-64. 
- "Moral Worth: Having It Both Ways." Journal of Philosophy 117, no. 10 (October 2020): 529-56.

Kant, Immanuel. Groundwork for the Metaphysics of Morals. Translated and edited by Allen W. Wood. New Haven: Yale University Press, 2018.

Keshet, Ezra, and Florian Schwartz. "De Re/De Dicto." In The Oxford Handbook of Reference, edited by Jeanette Gundel and Barbara Abbott, 168-202. Oxford: Oxford University Press, 2019.

Lillehammer, Hallvard. "Smith on Moral Fetishism." Analysis 57, no. 3 (July 1997): 187-95.

Markovits, Julia. "Acting for the Right Reasons." Philosophical Review 119, no. 2 (April 2010): 201-42.

Olson, Jonas. "Are Desires De Dicto Fetishistic?” Inquiry 45, no. 1 (2002): 89-96. Philips-Brown, Milo, and Lyndal Grant. "Getting What You Want." Philosophical Studies 177, no. 7 (July 2020): 1791-1810.

Portmore, Douglas W. "Moral Worth and Our Ultimate Moral Concerns." Oxford Studies in Normative Ethics, forthcoming.

Sharvit, Yael. "Embedded Questions and 'De Dicto' Readings.” Natural Language Semantics 10, no. 2 (2002): 97-123.

Sliwa, Paulina. "Moral Worth and Moral Knowledge." Philosophy and Phenomenological Research 93, no. 2 (September 2016): 393-418.

Smith, Michael. The Moral Problem. Malden, MA: Blackwell, 1994.

Stratton-Lake, Philip. Kant, Duty, and Moral Worth. London: Routledge, 2000.

Von Fintel, Kai, and Irene Heim. "Beyond De Re/De Dicto: The Third Reading." Intensional Semantics. Unpublished manuscript, 2011.

Williams, Bernard. "Persons, Character, and Morality." In Moral Luck, 1-19. Cambridge: Cambridge University Press, 1981.

Woods, Jack. "Logical Indefinites." Logique et Analyse 57, no. 227 (September 2014): 277-307. 